\title{
Evidence for Chloroquine/Hydroxychloroquine in the Treatment of COVID-19
}

\author{
Rajesh M Shetty ${ }^{1}$, ArunKumar Namachivayam² ${ }^{2}$
}

\begin{abstract}
Introduction: Given the current lack of an approved and effective treatment or vaccine for severe acute respiratory syndrome coronavirus-2 (SARS-CoV-2), repositioning old drugs for use as an antiviral treatment is an interesting strategy because knowledge about these drugs' safety profile, posology, and drug interactions is already known. Chloroquine and hydroxychloroquine, widely used as antimalarial and autoimmune disease drugs, have recently been reported as a potential broad-spectrum antiviral drug.

Background:The in vitro antiviral activity of chloroquine has been identified since the late 1960 s. However, antiviral mechanisms of chloroquine remain speculative. Several clinical trials have been conducted to test the efficacy and safety of chloroquine or hydroxychloroquine in the treatment of COVID-19-associated pneumonia. The quality of the studies and the outcomes are evaluated in this systematic review and meta-analysis.

Review results: Literature review revealed 23 clinical studies. Only 9 of 23 studies were randomized controlled trials. Of nine randomized controlled trials, only study by Skipper et al. was deemed to be at low risk of bias. All studies evaluated variedwith different outcomes. Mechanical ventilation and virological clearance were the only common outcomes evaluated in more than two studies. Virological clearance odds ratio (OR) was 1.25 (95\% confidence interval $[\mathrm{Cl}]$ of $0.57-2.73 ; \mathrm{Chi}^{2}=0.83 ; \mathrm{I}^{2}=0 \%$ ). GRADE quality of evidence was downgraded by three levels to very low due to concerns about the risk of bias, inconsistency, and imprecision. For mechanical ventilation, OR was $1.09\left(95 \% \mathrm{Cl} 0.80-1.50 ; \mathrm{Chi}^{2}=0\right.$; $\mathrm{I}^{2}=0$ ). GRADE quality of evidence was downgraded by two levels to low due to concerns about the risk of bias and imprecision. There was no statistically significant difference between the groups for these two outcomes.

Conclusion: As per the available evidence, based on our review, we conclude that hydroxychloroquine/chloroquine has not shown to be beneficial when used for the treatment of patients with COVID-19 pneumonia.

Keywords: Acute hypoxemic respiratory failure (AHRF), Chloroquine, Coronavirus disease 2019, COVID-19 drug treatment, Hydroxychloroquine. Indian Journal of Critical Care Medicine (2021): 10.5005/jp-journals-10071-23773
\end{abstract}

\section{BACKGROUND}

\section{COVID-19}

In December 2019, a new virus, severe acuterespiratory syndrome coronavirus 2 (SARS-CoV-2), emerged in China. Initial cases were reported from people working in the seafood wholesale market in Wuhan, capital city of Hubei province in Central China. ${ }^{1}$ The researchers sequenced a novel beta-coronavirus, the genome with $86.9 \%$ identity to a previously published bat SARS-like CoV genome (bat-SL-CoVZC45, MG772933). ${ }^{1}$ This virus was distinct from human SARS-CoV and Middle East respiratory syndrome coronavirus (MERS-CoV). ${ }^{2}$ The World Health Organization (WHO) officially named the disease caused by this virus as coronavirus disease -2019 (COVID-19). . COVID-19 caused by SARS-CoV-2 ischaracterized byserious injuries to the lungs. The incubation period is about 14 days. Common presenting features are flu-like illnesses with lower respiratory tract symptoms.

WHO declared COVID-19 outbreak as global pandemic on March 11, 2020. Despite drastic containment measures, the virus is spreading extensively. As of January 3,2021 , the infection was reported from 222 countries globally, 8,25,79,768 patients have been confirmed to have COVID-19, and 18,18,849 of them have died. ${ }^{4}$ The experts and researchers have been trying hard to find rapid diagnostic and therapeutic agents to counter the disease. ${ }^{5}$
${ }^{1}$ Department of Critical Care Medicine, Manipal Hospital Whitefield, Bengaluru, Karnataka, India

${ }^{2}$ Department of Data Science, Alke Research Private Limited, Bengaluru, Karnataka, India

Corresponding Author: Rajesh M Shetty, Department of Critical Care Medicine, Manipal Hospital Whitefield, Bengaluru, Karnataka, India, e-mail: drrajeshshetty@gmail.com

How to cite this article: Shetty RM, Namachivayam A. Evidence for Chloroquine/Hydroxychloroquine in the Treatment of COVID-19. Indian J Crit Care Med 2021;25(4):441-452.

Source of support: Nil

Conflict of interest: None

\section{Chloroquine/Hydroxychloroquine}

Repositioning old drugs for use as an antiviral treatment gained prominence in the beginning of the pandemic because the safety profile, side effects, posology, and drug interactions of these drugs are already known. ${ }^{6,7}$ Many agents including Western medicines, natural products, and traditional Chinese medicines have shown potential efficacy against COVID-19. ${ }^{8}$ Drugs, such as ribavirin, interferon, lopinavir-ritonavir, and corticosteroids,

(0) Jaypee Brothers Medical Publishers. 2021 Open Access This article is distributed under the terms of the Creative Commons Attribution 4.0 International License (https://creativecommons.org/licenses/by-nc/4.0/), which permits unrestricted use, distribution, and non-commercial reproduction in any medium, provided you give appropriate credit to the original author(s) and the source, provide a link to the Creative Commons license, and indicate if changes were made. The Creative Commons Public Domain Dedication waiver (http://creativecommons.org/publicdomain/zero/1.0/) applies to the data made available in this article, unless otherwise stated. 
have been used in patients with SARS or MERS. ${ }^{9}$ Chloroquine is used in the treatment of malaria, rheumatoid arthritis, and lupus erythematosus. Chloroquine and its derivative, hydroxychloroquine, are inexpensive and safe drugs. They have been used for more than 70 years. The commonest side effect reported is eye damage after long-term use. ${ }^{10}$ Both chloroquine and hydroxychloroquine have shown broad-spectrum antiviral effects. ${ }^{11,12}$

\section{How does Chloroquine/Hydroxychloroquine Work?}

In vitro studies have shown antiviral activity of chloroquine since the late 1960 s. ${ }^{13-15}$ Growth of many viruses can be inhibited in cell culture by both chloroquine and hydroxychloroquine, including the SARS-CoV. ${ }^{16}$ Hydroxychloroquine sulfate was first synthesized in 1946 by introducing a hydroxyl group into chloroquine and this is much less ( 40\%) toxic than chloroquine in animals. ${ }^{17}$ Previous studies have shown that chloroquine has therapeutic activity against many viruses, ${ }^{18}$ including human coronavirus OC43 in animal model ${ }^{19}$ and SARS-CoV in cell culture studies. ${ }^{20}$ But antiviral mechanisms of chloroquine are not clearly confirmed. ${ }^{21}$

Both chloroquine and hydroxychloroquine are weak bases and elevate the $\mathrm{pH}$ of acidic intracellular organelles (endosomes/ lysosomes) and inhibit $\mathrm{pH}$-dependent viral fusion/replication ${ }^{22}$ (Fig. 1). It also interferes with viral envelope glycoprotein and glycosylation of host cellular receptors of SARS-CoV. ${ }^{12,18,20}$ In addition, chloroquineinhibits SARS-CoV entry by changing the glycosylation of angiotensin-converting enzyme 2 (ACE2) receptors and spikeproteins. ${ }^{10}$ In vitro time-of-addition assay

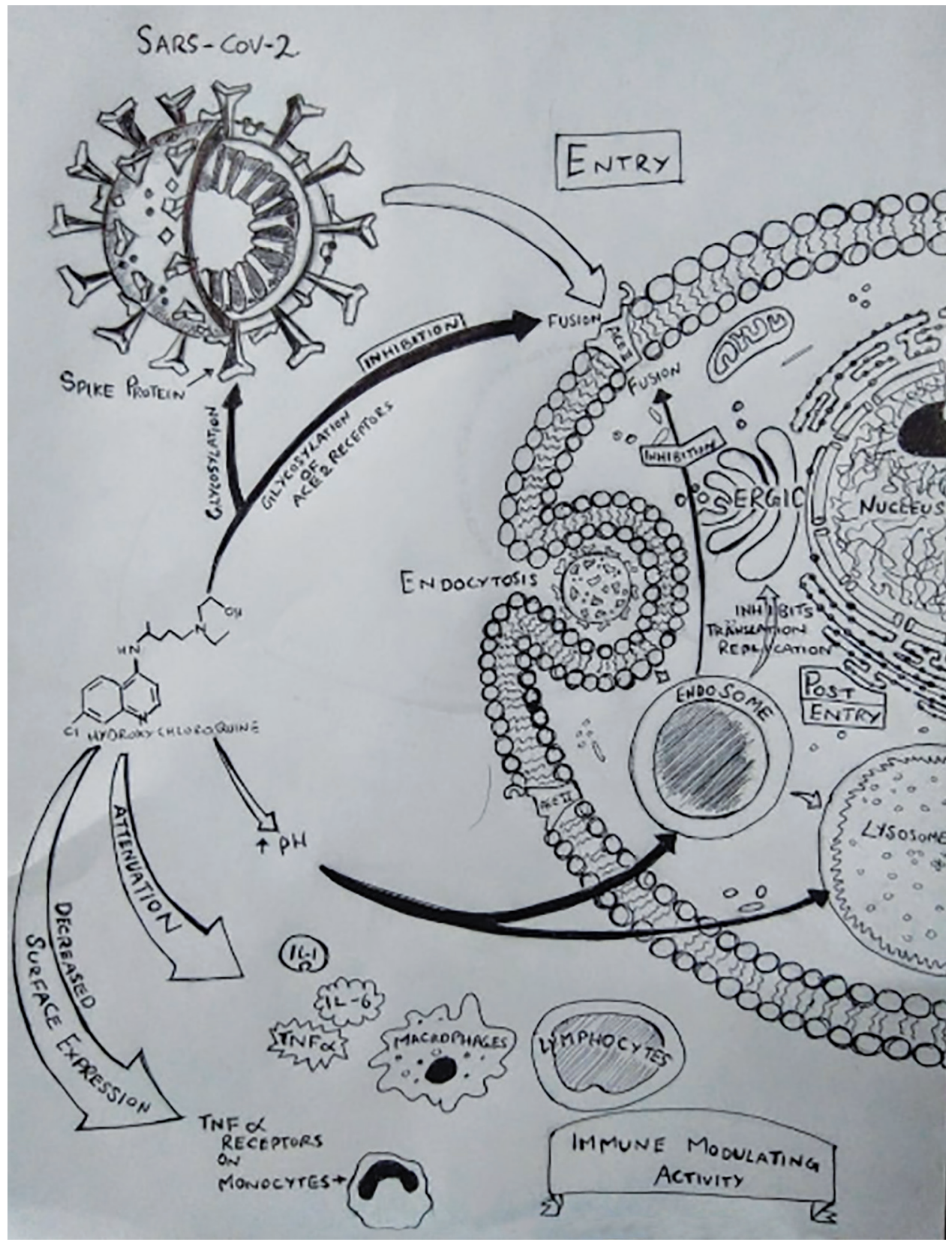

Fig. 1: Mechanism of action 
demonstrated that chloroquine effectively inhibits both at entry and at postentry stages of the 2019-nCoV infection in Vero E6 cells. $^{23,24}$ In the in vitro studies, chloroquine blocked COVID-19 infection at a low-micromolar concentration, with a half-maximal effective concentration (EC50) of $1.13 \mu \mathrm{M}$ and a half cytotoxic concentration (CC50) greater than $100 \mathrm{Mm}$ and also showed a high selectivity index $([\mathrm{SI}]>88.50) .{ }^{18,25}$ Chloroquine also inhibits virion assembly in endoplasmic reticulum-Golgi intermediate compartment-like structures. It is possible that chloroquine exhibits host effects, independent of direct viral action, by attenuating the expression of proinflammatory factors and receptors, ${ }^{18}$ which induces acute respiratory distress syndrome, the primary reason for coronavirus-associated mortality. ${ }^{2}$ This immune-modulating activity of chloroquine possibly enhances its antiviral effect in vivo synergistically. After oral administration, chloroquine is widely distributed in the whole body. The EC90 value of chloroquine against the 2019-nCoV in VeroE6 cells was $6.90 \mu \mathrm{M}$. This is clinically achievable and demonstrated in the plasma of rheumatoid arthritis patients after receivingdoses of $500 \mathrm{mg} /$ day. ${ }^{26}$

\section{Why is it Important to do this Review?}

Several clinical trials have been conducted to test the efficacy and safety of chloroquine or hydroxychloroquine in the treatment of COVID-19-associated pneumonia.Studies consist of various methodologies, designs for control groups (none, different antivirals, placebo, etc.), and varied outcome measures. The final interpretation is therefore technically demanding, and it is difficult to reach any firm conclusion. ${ }^{27}$ With this review, we aim to answer the question if there is any benefit of chloroquine/ hydroxychloroquine in the treatment of patients with COVID-19.

\section{Aim and Objective}

Review of evidence for the benefit of chloroquine/ hydroxychloroquine in the treatment of patients with COVID-19.

\section{Materials and Methods}

\section{Search Methods for Identification of Studies Electronic Searches}

We searched the latest issue of the Cochrane Central Register of Controlled Trials (CENTRAL, Issue 1 of 12, January 2021), including Embase, CINAHL, and PubMed. We searched Open Grey for information on Grey Literature. We used the search terms COVID, coronavirus, hydroxychloroquine, and chloroquine. We limited the time to last 1 year. We did not impose any language restrictions (Flowchart 1).

\section{Searching Other Resources}

We screened the reference lists of all eligible trials and relevant reviews.

Flowchart 1: Study flow diagram

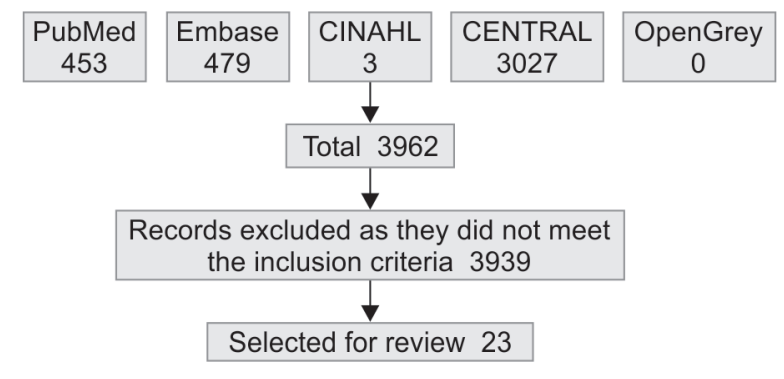

\section{Criteria for Considering Studies for this Review}

Types of Studies

We included all studies comparing chloroquine/hydroxychloroquine with any other treatment protocols, which do not include chloroquine or hydroxychloroquine in hospitalized patients for the treatment of COVID-19, regardless of language and publication status.

\section{Types of Participants}

We included all studies conducted in COVID-19 patients as per author's criteria.

\section{Types of Intervention}

The intervention group comprised all participants who were treated with either chloroquine or hydroxychloroquine. The control group included all participants who were treated with any other medications, except chloroquine or hydroxychloroquine.

\section{Types of Outcome Measures}

We included all the outcomes reported by the authors as listed below:

- Reduction in all-cause hospital mortality

- Inhibiting the exacerbation of pneumonia

- Improving lung imaging findings

- Promoting virus-negative conversion

- Shortening the disease course

- Reduced need for escalation of respiratory support

\section{Assessment of Risk of Bias in Included Studies}

We assessed the risk of bias using the Cochrane "risk of bias" tool. We included only randomized controlled trials (RCTs) for risk of bias assessment. We assumed other methodologies at high risk of bias. Names of the study authors, institutions, journals, and results were not concealed. We judged the quality of studies on the basis of the risk of bias in the following domains:

- Selection bias

o Random sequence generation

o Allocation concealment

- Detection bias

o Blinding of outcome assessors

o Blinding of personnel

- Attrition bias

o Incomplete outcome data

- Reporting bias

o Selective reporting

We classified the studies as low risk, high risk, or unclear risk of bias for the above domains using information available from the studies. Studies were considered low risk of bias if all domains were assessed as adequate (low risk). Studieswereconsidered high risk of bias if one or more domains were assessed as inadequate (high or unclear risk), and as unclear risk if insufficient details of what happened in the study werereported.

We have presented a "risk of bias" table (Fig. 2) and a "risk of bias" graph (Fig. 3).

\section{Measurement of Treatment Effect}

We undertook analysis using RevMan 5.4.1 software.

For continuous outcomes, we presented the treatment effect as a mean difference (MD). Effect estimates along with $95 \%$ confidence intervals $(\mathrm{Cl})$ are presented. 


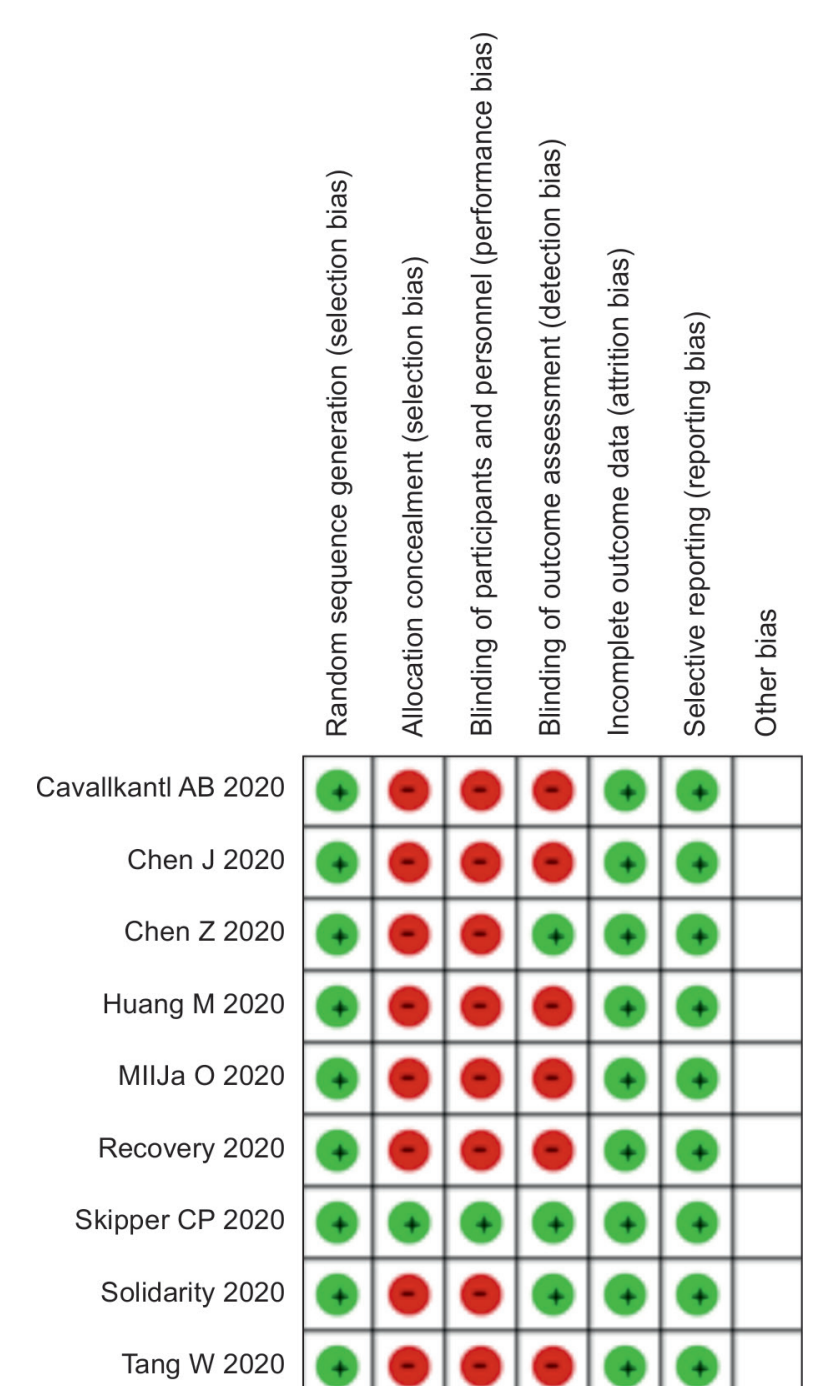

Fig. 2: Risk of bias table

\section{Assessment of Heterogeneity}

We had planned not to perform a meta-analysis if we suspected an important clinical heterogeneity on examination of the included studies. We used the chi-squarestatistic to test statistical heterogeneity between studies and considered a $p \leq 0.10$ indicating significant heterogeneity; we used the $\mathrm{I}^{2}$ statistic to assess the magnitude of heterogeneity. ${ }^{28}$ We considered that an $\mathrm{I}^{2}>50 \%$ would indicate problematic heterogeneity between studies and, in such cases, we would carefully consider the value of any pooled analyses. To determine the best estimate of the intervention effect, we used a fixed-effect model. We prepared forest plots, summarizing findings from the included studies.

\section{Assessment of Reporting Biases}

Comprehensive electronic search was carried out to minimize the effects of publication bias. As we had very few eligible studies, funnel plots of effect estimate against their standard errors (on a reverse scale) to differentiate asymmetry due to publication bias were not created as per the guideline.

\section{Data Synthesis}

We used the Cochrane's statistical software (RevMan 5.4.1) for analysis. We expressed risk ratios for proportionsand pooled estimates of MD for continuous variables.

Results are presented in the form of forest plots (Figs 4 and 5).

\section{"Summary of Findings" Table and GRADE}

"Summary of findings" table (Table 1) includes a list of all important outcomes, the number of participants and studies addressing each outcome, and a grade for the overall quality of the body of evidence for each outcome. GRADE system is used to assess the quality of body of evidence associated with specific outcomes (virological clearance and mechanical ventilation). Evaluation considerswithinstudy risk of bias, directness of the evidence, heterogeneity of data, precision of effect estimates, and risk of publication bias. ${ }^{29}$

\section{Discussions}

\section{Summary of Main Results}

Literature review revealed 23 clinical studies (Flowchart 1). All the 23 studies are briefly described in Table 2 . Only 9 of 23 studies were RCTs. All studies evaluated varied withdifferent outcomes. The outcomes reported in these studies are described in Table 3. Even when the same outcomeswereevaluated, the tool used for evaluating the outcomes wasdifferent (e.g., all-cause 28-day mortality, in-hospital mortality, and survival benefit). Mechanical ventilation and virological clearance were the only common outcomes evaluated in more than two studies. Forest plots of these two outcomes are included in Figures 4 and 5. For virological

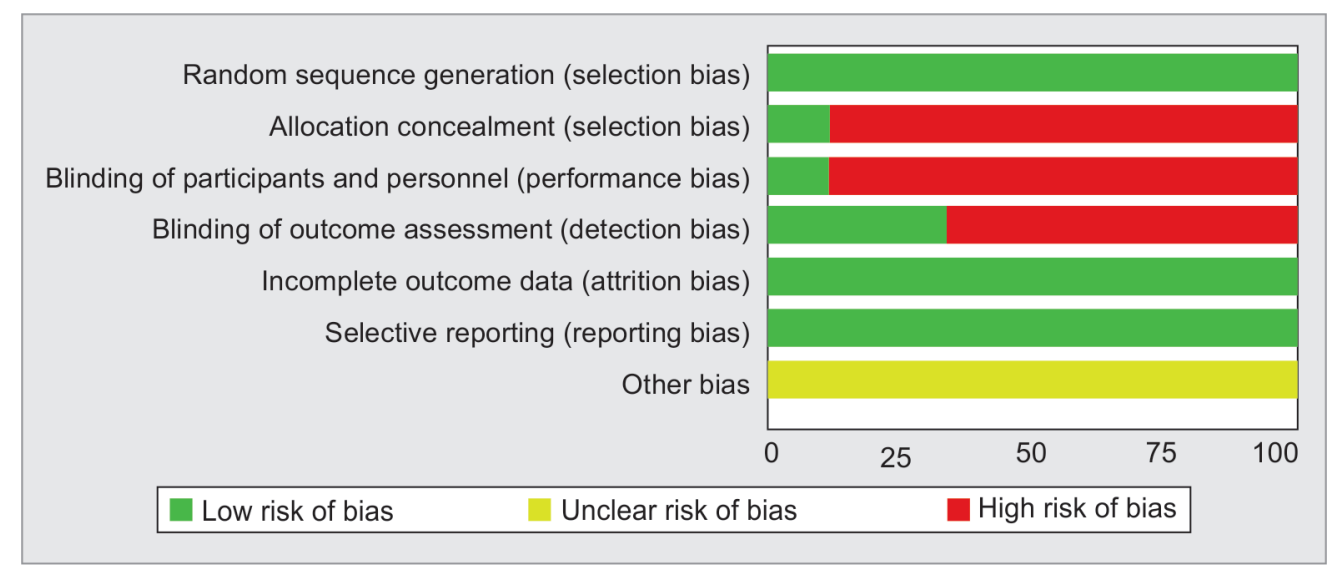

Fig. 3: Risk of bias graph 


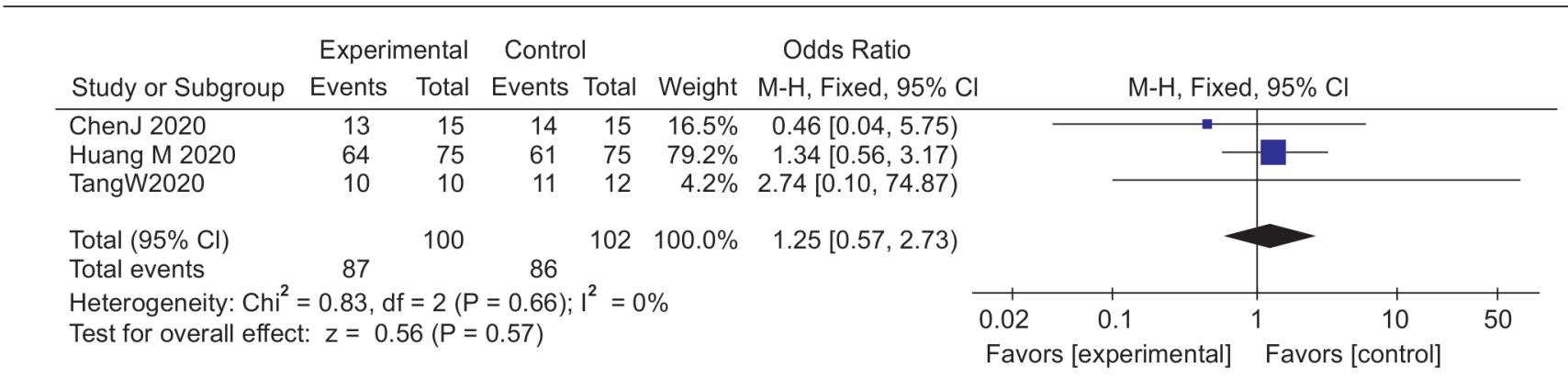

Fig. 4: Virological clearance

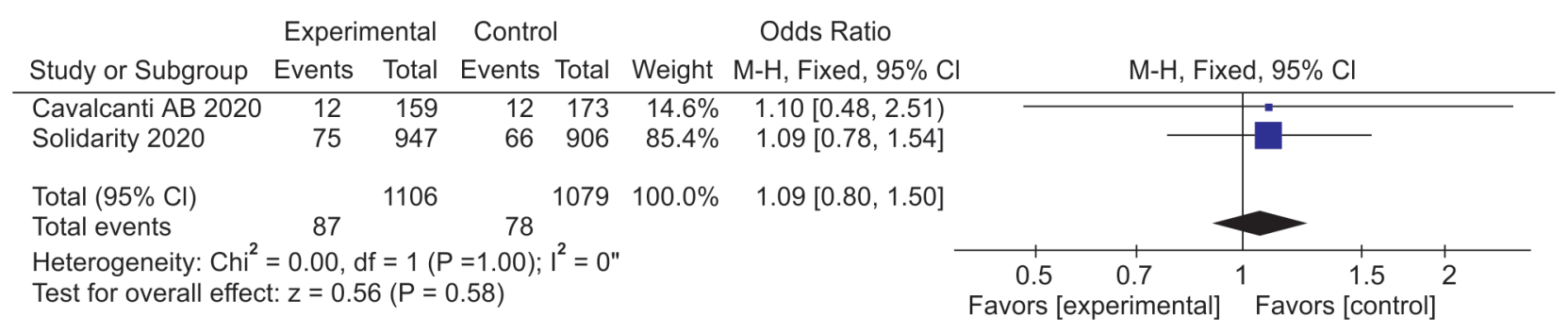

Fig. 5: Forest plot mechanical ventilation

Table 1: GRADE summary of findings

\begin{tabular}{|c|c|c|c|c|c|c|}
\hline \multicolumn{7}{|c|}{ Hydroxychloroquine/chloroquine compared to usual care in patients with COVID-19 } \\
\hline \multicolumn{7}{|c|}{$\begin{array}{l}\text { Patient or population: Patients with COVID-19 } \\
\text { Setting: } \\
\text { Intervention: Hydroxychloroquine/chloroquine } \\
\text { Comparison: Usual care }\end{array}$} \\
\hline & \multicolumn{2}{|c|}{ Anticipated absolute effects* $(95 \% \mathrm{Cl})$} & \multirow[b]{2}{*}{$\begin{array}{l}\text { Relative effect } \\
(95 \% \mathrm{CI})\end{array}$} & \multirow[b]{2}{*}{$\begin{array}{l}\text { No of participants } \\
\text { (studies) }\end{array}$} & \multirow[b]{2}{*}{$\begin{array}{l}\text { Certainty of the } \\
\text { evidence (GRADE) }\end{array}$} & \\
\hline Outcomes & $\begin{array}{l}\text { Risk with usual } \\
\text { care }\end{array}$ & $\begin{array}{l}\text { Risk with hydroxychloroquine/ } \\
\text { chloroquine }\end{array}$ & & & & Comments \\
\hline $\begin{array}{l}\text { Virological } \\
\text { clearance }\end{array}$ & 843 per 1,000 & 870 per $1,000(754-936)$ & $\begin{array}{l}\text { OR } 1.25 \\
(0.57-2.73)\end{array}$ & 202 (3 RCTs) & $\begin{array}{l}\oplus O O O \\
\text { VERY LOW }\end{array}$ & \\
\hline $\begin{array}{l}\text { Mechanical } \\
\text { ventilation }\end{array}$ & 72 per 1,000 & 78 per $1,000(59-105)$ & $\begin{array}{l}\text { OR } 1.09 \\
(0.80-1.50)\end{array}$ & 2,185 (2 RCTs) & $\begin{array}{l}\oplus \mathrm{OOO} \\
\text { VERY LOW }\end{array}$ & \\
\hline
\end{tabular}

*The risk in the intervention group (and its $95 \% \mathrm{Cl}$ ) is based on the assumed risk in the comparison group and the relative effect of the intervention (and its $95 \% \mathrm{Cl}$ ); $\mathrm{Cl}$, confidence interval; OR: odds ratio

\section{GRADE working group grades of evidence}

High certainty: We are very confident that the true effect lies close to that of estimate of effect

Moderate certainty: We are moderately confident in the effect estimate: The true effect is likely to be close to the estimate of effect, but there is a possibility that it is substantially different

Low certainty: Our confidence in the effect estimate is limited: The true effect may be substantially different from the estimate of effect Very low certainty: We have very little confidence in the effect estimate: The true effect is likely to be substantially different from the estimate of effect

Explanations: a. Allocation concealment, blinding of participants, and blinding of outcomes are assessed inadequately in all the three studies; b. Huang $\mathrm{M}$ and Tang studies showed benefits, whereas Chen J study showed no benefit; $\mathrm{C}$. Large $\mathrm{Cl}$; $\mathrm{d}$. Allocation concealment and blinding of participants are assessed inadequately in both the studies; e. Large $\mathrm{Cl}$

clearance, odds ratio (OR) was 1.25 (95\% Cl of 0.57-2.73; $\mathrm{Chi}^{2}=0.83$; $\mathrm{I}^{2}=0 \%$ ). GRADE quality of evidence was downgraded to very low due to concerns about the risk of bias, inconsistency, and imprecision. For mechanical ventilation, OR was 1.09 (95\% $\mathrm{Cl} 0.80$ $\left.1.50 ; \mathrm{Chi}^{2}=0 ; \mathrm{I}^{2}=0\right)$. GRADE quality of evidence was downgraded to low due to concerns about the risk of bias and imprecision. There was no statistically significant difference between the groups for these two outcomes.

\section{Quality of Evidence}

Of nine RCTs, only study by Skipper et al. was deemed to be at low risk of bias (Figs 2 and 3). However, in the Skipper et al. study, the 


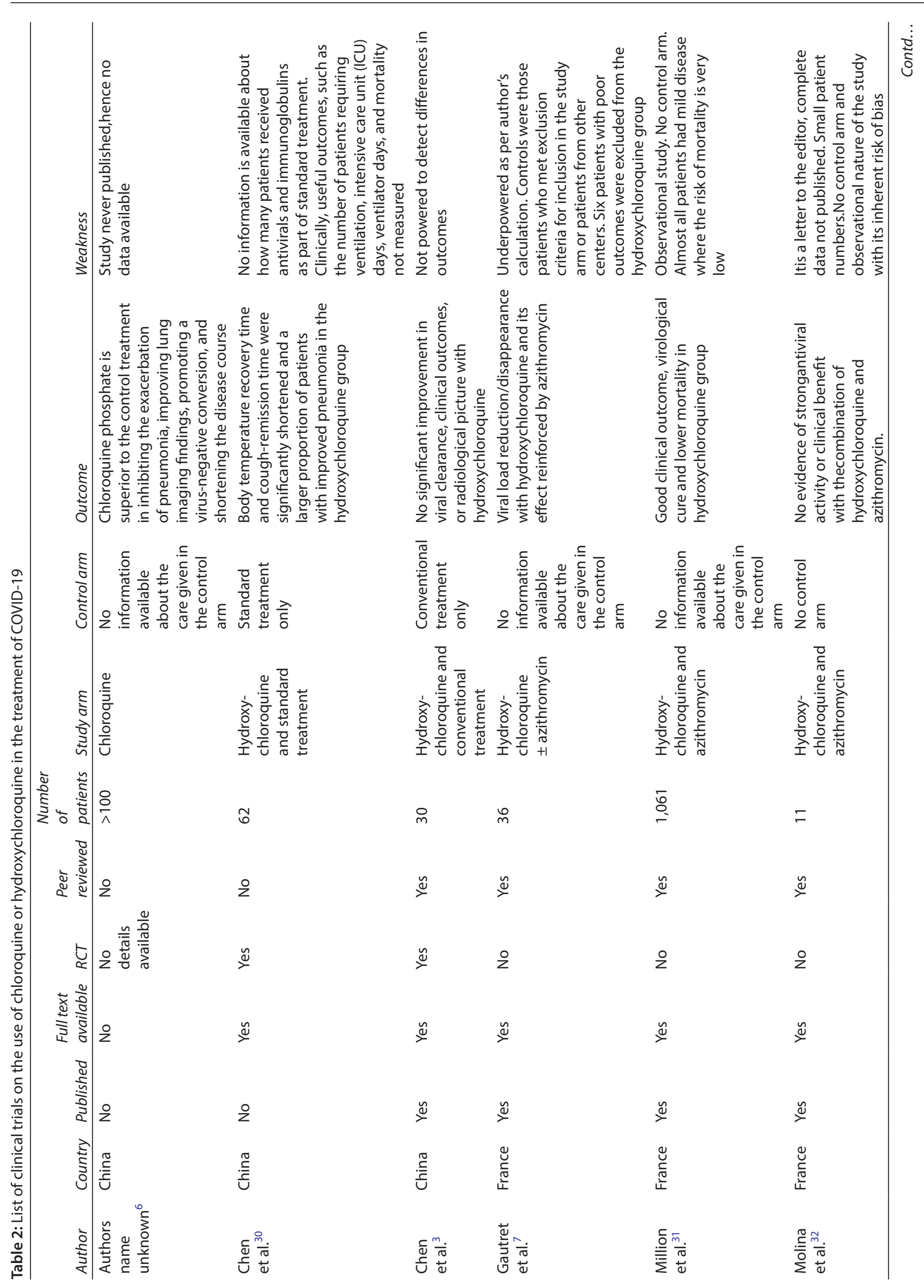




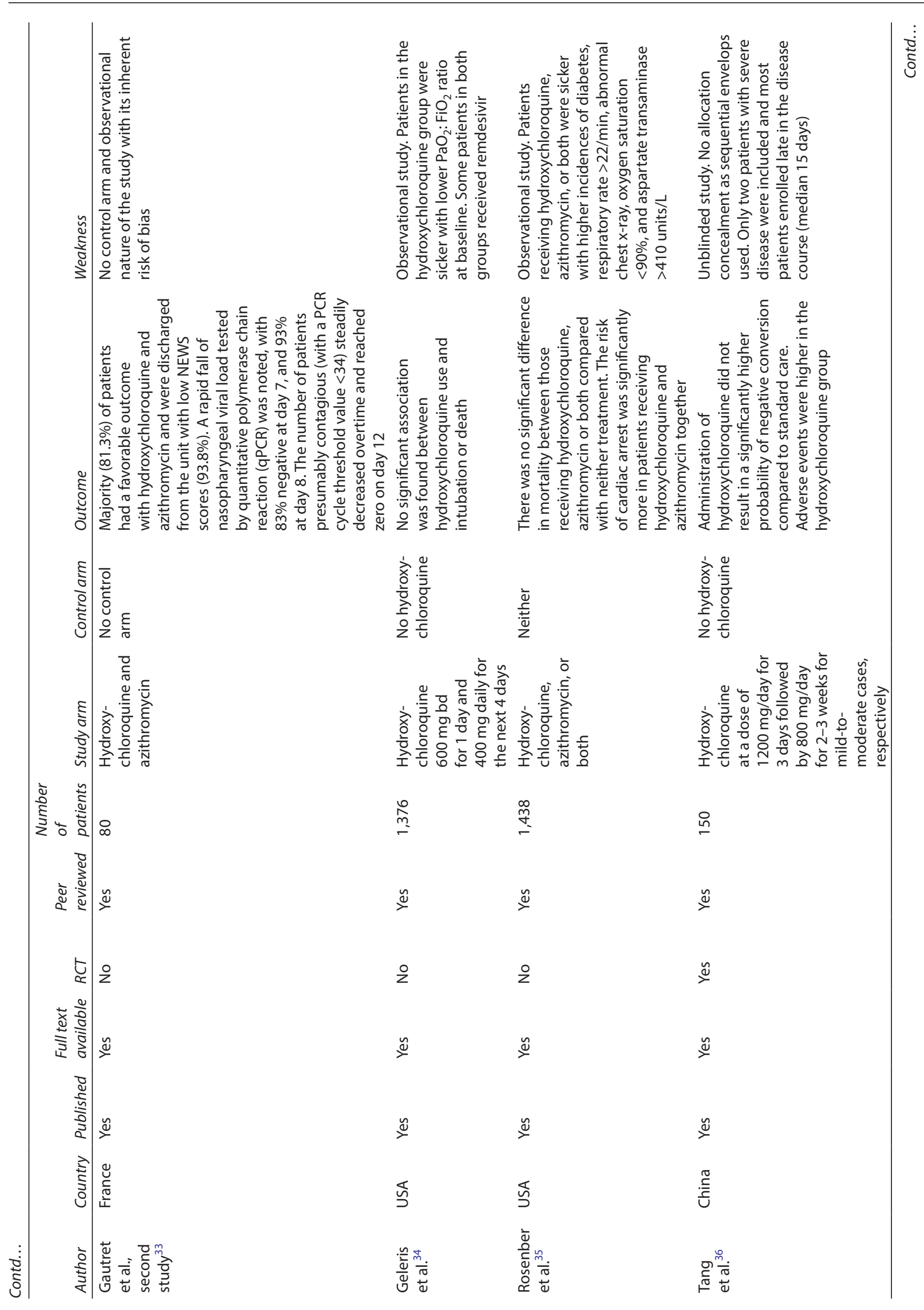




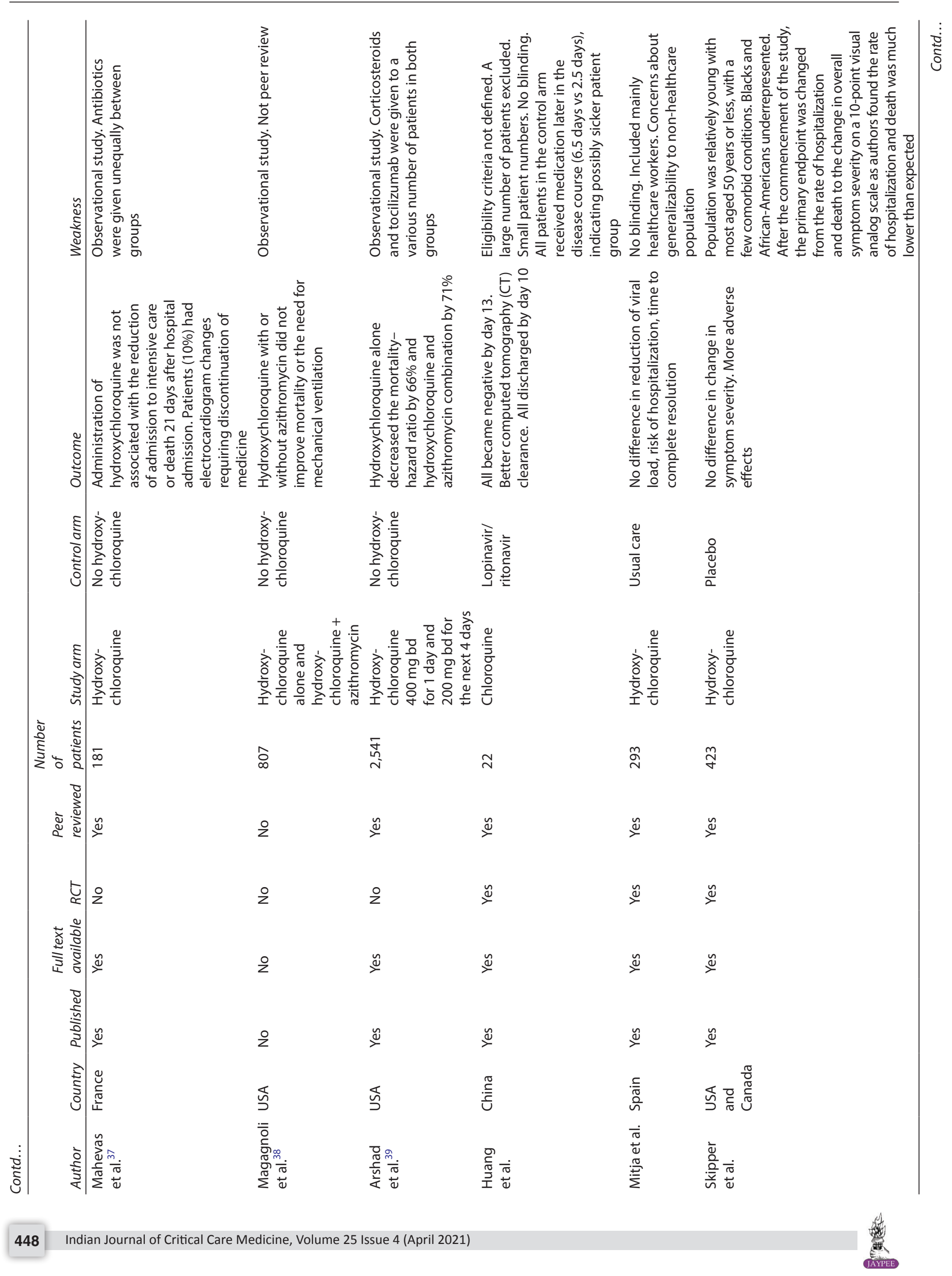




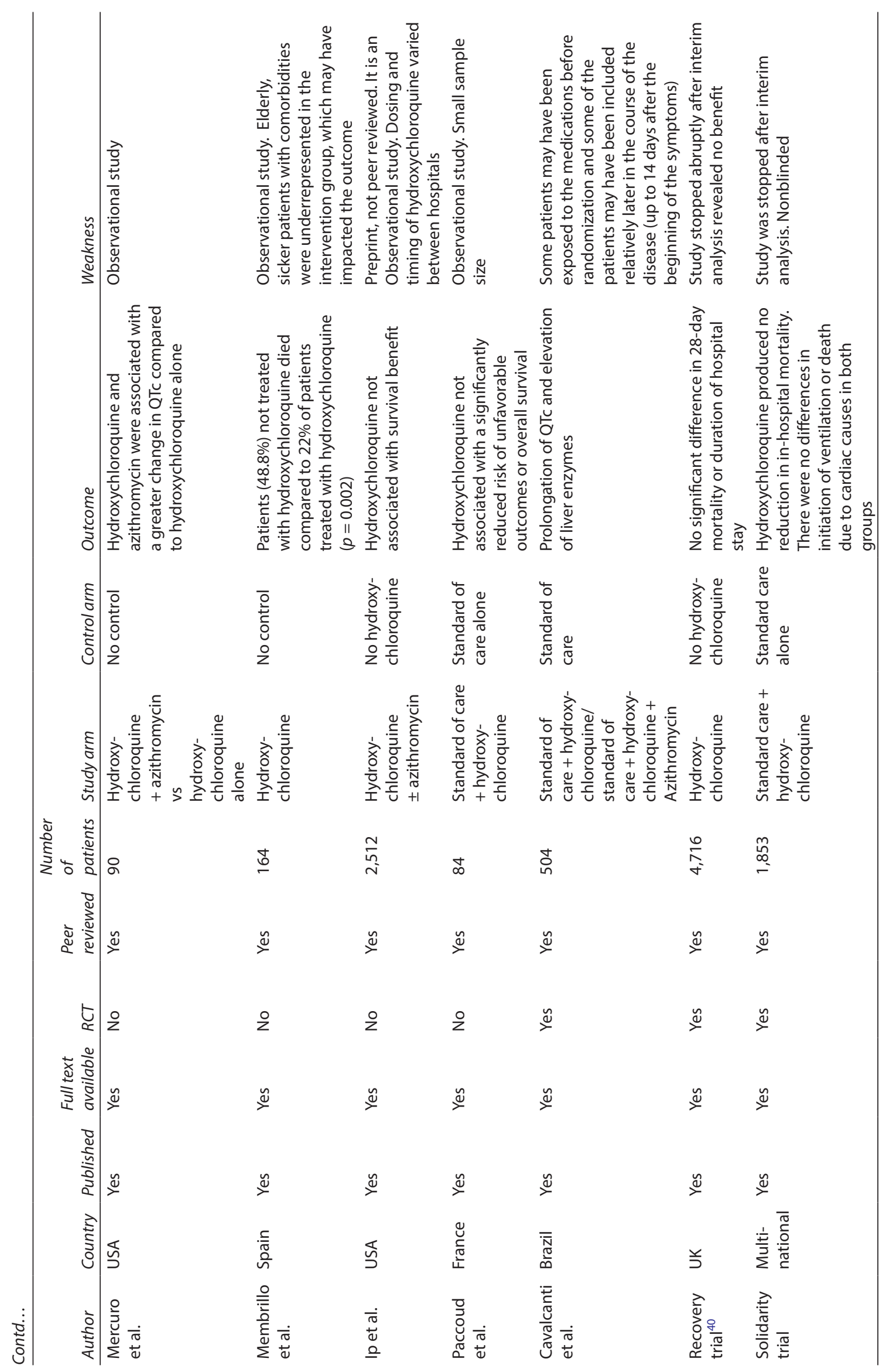


Table 3: Reported outcomes in various studies

\begin{tabular}{|c|c|c|c|}
\hline Author & Type of study & Outcome & Results \\
\hline Recovery & $\mathrm{RCT}$ & $\begin{array}{l}\text { All-cause 28-day } \\
\text { mortality }\end{array}$ & $\begin{array}{l}27 \% \text { hydroxychloroquine group vs } 25 \% \text { usual care; rate ratio } 1.09,95 \% \\
\mathrm{Cl} 0.97-1.23, p=0.15\end{array}$ \\
\hline Solidarity & $\mathrm{RCT}$ & In-hospital mortality & Death rate $1.19,0.89-1.59, p=0.23$ \\
\hline Million & Observational study & Overall case fatality rate & Overall case fatality rate was $0.9 \%$ \\
\hline Geleris & Observational study & $\begin{array}{l}\text { Composite of intubation } \\
\text { and death }\end{array}$ & Hazard ratio (HR) 1.04, 95\% Cl 0.82-1.32 \\
\hline Rosenberg & Observational study & In-hospital mortality & $\begin{array}{l}\text { The probability of death for patients receiving } \\
\text { hydroxychloroquine + azithromycin was } 25.7 \%, 95 \% \mathrm{Cl} 22.3-28.9 \% \text {; } \\
\text { hydroxychloroquine alone } 19.9 \%, 95 \% \mathrm{Cl} 15.2-24.7 \% \text {; and neither drug } \\
12.7 \%, 95 \% \mathrm{Cl} 8.3-17.1 \%\end{array}$ \\
\hline Mahvesa & Observational study & Death at 21 days & $\begin{array}{l}\text { Overall survival at day } 21 \text { was } 89 \% \text { in the treatment group and } 91 \% \text { in } \\
\text { the control group (HR } 1.2,0.4-3.3 \text { ) }\end{array}$ \\
\hline Arshad & Observational study & Mortality-hazard ratio & $\begin{array}{l}\text { Crude mortality was } 13.5 \% \text { with hydroxychloroquine alone, } 20 \% \text { with } \\
\text { hydroxychloroquine and azithromycin together, and } 26.45 \% \text { with } \\
\text { neither of the medications ( } p<0.001)\end{array}$ \\
\hline Magagnoli & Observational study & Mortality & $\begin{array}{l}\text { Hydroxychloroquine with or without azithromycin compared to neither } \\
\text { did not improve mortality }(19.2,22.2 \text { and } 9.4 \%, p<0.001)\end{array}$ \\
\hline Membrillo & Observational study & Death & $\begin{array}{l}\text { Patients }(48.8 \%) \text { not treated with hydroxychloroquine died compared to } \\
22 \% \text { of patients treated with hydroxychloroquine }(p=0.002)\end{array}$ \\
\hline Ip A & Observational study & Survival benefit & $\begin{array}{l}\text { Use of hydroxychloroquine with or without cotreatment with } \\
\text { azithromycin was not associated with a reduction in mortality } \\
\text { (adjusted } \mathrm{HR}, 0.99,95 \% \mathrm{Cl} 0.80-1.22 \text {. Unadjusted } 30 \text {-day mortality for } \\
\text { patients receiving hydroxychloroquine alone, azithromycin alone, the } \\
\text { combination, or neither drug was } 25,20,18 \text {, and } 20 \% \text {, respectively }\end{array}$ \\
\hline Paccoud & Observational study & Overall survival & $\begin{array}{l}\text { Overall survival was not significantly different between the two groups } \\
(\text { HR } 0.89[0.23-3.47], p=1)\end{array}$ \\
\hline Unknown authors & Unknown & Pneumonia resolution & No data available \\
\hline Chen & $\mathrm{RCT}$ & Pneumonia resolution & $\begin{array}{l}\text { A larger proportion of patients with improved pneumonia in the } \\
\text { hydroxychloroquine group }(80.6 \%, 25 \text { of } 31) \text { compared to control group } \\
(54.8 \%, 17 \text { of } 31)\end{array}$ \\
\hline Unknown authors & Unknown & Radiological clearance & No data available \\
\hline Chen & $\mathrm{RCT}$ & Radiological clearance & $\begin{array}{l}\text { Radiological progression was shown on CT images in five cases }(33.3 \%) \\
\text { of the hydroxychloroquine group and seven cases ( } 46.7 \%) \text { of the control } \\
\text { group }\end{array}$ \\
\hline Huang & $\mathrm{RCT}$ & Radiological clearance & $\begin{array}{l}\text { By day } 9,60 \% \text { of patients in the chloroquine group reached lung } \\
\text { clearance, compared to } 25 \% \text { from the lopinavir/ritonavir group. By day } \\
14 \text {, the incidence rate of lung improvement based on CT imaging from } \\
\text { the chloroquine group was more than doubled to that of the lopinavir/ } \\
\text { ritonavir group (rate ratio } 2.21,95 \% \mathrm{Cl} 0.81-6.62 \text { ) }\end{array}$ \\
\hline Unknown authors & Unknown & Viral clearance & No data available \\
\hline Chen J & $\mathrm{RCT}$ & Viral clearance & $\begin{array}{l}\text { COVID-19 nucleic acid of throat swabs was negative on day } 7 \text { in } 86.7 \% \\
\text { of cases in the hydroxychloroquine group and } 93.3 \% \text { of the control } \\
\text { group }(p>0.05)\end{array}$ \\
\hline Gautret & Observational study & Viral clearance & $\begin{array}{l}\text { At day } 6,70 \% \text { of hydroxychloroquine-treated patients was virologically } \\
\text { cured, compared to } 12.5 \% \text { in the control group }(p=0.001) \text {. Patients } \\
(100 \%) \text { treated with hydroxychloroquine and azithromycin combination } \\
\text { were virologically cured, compared to } 57.1 \% \text { of patients treated with } \\
\text { only hydroxychloroquine }(p<0.001)\end{array}$ \\
\hline Million & Observational study & Viral clearance & $\begin{array}{l}\text { A good clinical outcome and virological cure was obtained in } 973 \\
\text { patients within } 10 \text { days }(91.7 \%)\end{array}$ \\
\hline $\begin{array}{l}\text { Gautret (second } \\
\text { study) }\end{array}$ & Observational study & Viral clearance & $\begin{array}{l}\text { A rapid fall of nasopharyngeal viral load tested by PCR was noted, with } \\
83 \% \text { negative at day } 7 \text { and } 93 \% \text { at day } 8\end{array}$ \\
\hline Tang & $\mathrm{RCT}$ & Viral clearance & $\begin{array}{l}\text { Probability of negative conversion by } 28 \text { days in the standard of care } \\
\text { plus hydroxychloroquine group was } 85.4 \%(95 \% \mathrm{Cl} 73.8-93.8 \%) \text {, similar } \\
\text { to that of in the standard-of-care group }(81.3 \%, 71.2-89.6 \%)\end{array}$ \\
\hline Huang & $\mathrm{RCT}$ & Viral clearance & $\begin{array}{l}\text { All patients on chloroquine became negative on day } 13 \text {, compared to } \\
\text { lopinavir/ritonavir group, where } 11 \text { of } 12 \text { turned negative at day } 14\end{array}$ \\
\hline
\end{tabular}




\begin{tabular}{|c|c|c|c|}
\hline Author & Type of study & Outcome & Results \\
\hline Mitja & $\mathrm{RCT}$ & Viral clearance & $\begin{array}{l}\text { No significant differences were found in the mean reduction of viral } \\
\text { load at day } 3(-1.41 \text { vs }-1.41 \text { Log } 10 \text { copies } / \mathrm{mL} \text { in the control and } \\
\text { intervention arm, respectively; difference of } 0.01[95 \% \mathrm{Cl}-0.28 ; 0.29]) \text { or } \\
\text { at day } 7(-3.37 \text { vs }-3.44 ; \mathrm{d}-0.07[-0.44 ; 0.29])\end{array}$ \\
\hline Molina & Observational study & Viral clearance & $\begin{array}{l}\text { Nasopharyngeal swabs using a qualitative PCR assay were still positive } \\
\text { for SARS-CoV-2 RNA in } 8 \text { of } 10 \text { patients }(80 \%, 95 \% \mathrm{Cl} \text { : 49-94) at days 5-6 } \\
\text { after treatment initiation }\end{array}$ \\
\hline Solidarity & $\mathrm{RCT}$ & Mechanical ventilation & No differences in initiation of ventilation (75 vs 66 ) \\
\hline Magagnoli & Observational study & Mechanical ventilation & $\begin{array}{l}\text { Risk of ventilation was similar in the hydroxychloroquine } \\
\text { group (adjusted } \mathrm{HR} 1.43,95 \% \mathrm{Cl} 0.53-3.79, p=0.48 \text { ) and in the } \\
\text { hydroxychloroquine and azithromycin group (adjusted } \mathrm{HR} 0.43,95 \% \mathrm{Cl} \\
0.16-1.12, p=0.09 \text { ) compared to the no hydroxychloroquine group }\end{array}$ \\
\hline Geleris & Observational study & $\begin{array}{l}\text { Composite of intubation } \\
\text { and death }\end{array}$ & HR $1.04,95 \% \mathrm{Cl} 0.82-1.32$ \\
\hline Cavalcanti & $\mathrm{RCT}$ & Mechanical ventilation & $\begin{array}{l}\text { Patients ( } 11 \%) \text { in the hydroxychloroquine + azithromycin group, } 7.5 \% \\
\text { in hydroxychloroquine alone group, and } 6.9 \% \text { in the control group } \\
\text { received mechanical ventilation during the first } 15 \text { days. Effect estimate } \\
\text { with } 95 \% \mathrm{Cl} \text { was } 1.77(0.81-3.87) \text { for hydroxychloroquine + azithromycin } \\
\text { vs control and } 1.15(0.49-2.70) \text { for hydroxychloroquine vs control }\end{array}$ \\
\hline Mercuro & Observational study & QTc prolongation & $\begin{array}{l}19 \% \text { of patients who received hydroxychloroquine monotherapy } \\
\text { developed prolonged QTc of } 500 \mathrm{~ms} \text { or more, and 3\% of patients had } \\
\text { a change in QTc of } 60 \mathrm{~ms} \text { or more. Of those who received concomitant } \\
\text { azithromycin, } 21 \% \text { had prolonged QTc of } 500 \mathrm{~ms} \text { or more and } 13 \% \text { had a } \\
\text { change in QTc of } 60 \mathrm{~ms} \text { or more }\end{array}$ \\
\hline Cavalcanti & $\mathrm{RCT}$ & QTc prolongation & $\begin{array}{l}\text { QTc duration more than } 480 \text { ms was seen in } 14.7 \% \text { of patients in the } \\
\text { hydroxychloroquine + azithromycin group, } 14.6 \% \text { of patients in the } \\
\text { hydroxychloroquine group, and } 1.7 \% \text { of patients who received neither } \\
\text { of the medications }\end{array}$ \\
\hline Solidarity & $\mathrm{RCT}$ & $\begin{array}{l}\text { Death during } 14 \text { days } \\
\text { with any cardiac cause }\end{array}$ & No difference (4 vs 2 ) \\
\hline Ip A & Observational study & $\begin{array}{l}\text { Death due to cardiac } \\
\text { causes }\end{array}$ & No difference (21 vs 16\%) \\
\hline
\end{tabular}

primary outcome was changed from the rate of hospitalization and death to the change in overall symptom severity on a 10-point visual analog scale. In this study, hydroxychloroquine did not significantly reduce symptom severity in early, mild COVID-19. This outcome was not analyzed in any other studies, making it difficult to compare the outcomes. Recovery and Solidarity trials are the two biggest studies. Both Recovery and Solidarity studies were stopped after interim analysis and outcome assessment wereunblinded.

\section{Conclusion}

Our analysis found 23 studies. Only nine were RCTs. Only one study was deemed as low risk of bias. Mechanical ventilationand virological clearance were the only common outcomes evaluated by more than two RCTs. There was no statistically significant difference between those who received hydroxychloroquine/ chloroquine and who did not for these outcomes. It is not possible to comment on other outcomes and adverse effects of hydroxychloroquine/chloroquine as they are not reported uniformly. As per the available evidence, based on our review, we conclude that hydroxychloroquine/chloroquine has not shown to be beneficial when used for the treatment of patients with COVID-19 pneumonia.

\section{ACKNOWLedgment}

We thank Dr. Rohith Rajan for his help in designing 'Figure 1: Mechanism of action'.

\section{OrCID}

Rajesh M Shetty $\odot$ https://orcid.org/0000-0002-9426-6701

ArunKumar Namachivayam (1) https://orcid.org/0000-0001-74468819

\section{References}

1. Huang C, Wang Y, Li X, Ren L, Zhao J, Hu Y. Clinical features of patients infected with 2019 novel coronavirus in Wuhan, China. Lancet 2020;395(10223):497-506. DOI: 10.1016/S0140-6736(20)30183-5.

2. Zhu N, Zhang D, Wang W, Li X, Yang B, Song J, et al. A novel coronavirus from patients with pneumonia in China, 2019. N Engl J Med 2020;382(8):727-737. DOI: 10.1056/NEJMoa2001017.

3. Chen J, Liu D, Liu L, Liu P, Xu Q, Xia L, et al. A pilot study of hydroxychloroquine in treatment of patients with common coronavirus disease 19 (COVID-19). J Zheijang Univ 2020 Mar;49(1):00. DOI: 10.3785/j.issn.1008-9292.2020.03.03.

4. Coronavirus Disease (COVID-19) pandemic. World Health Organization (cited 2021 January 03). Available from: https://www. who.int/emergencies/diseases/novel-coronavirus-2019. 
5. Devaux CA, Rolain JM, Coloson P, Raoult D. New insights on the antiviral effects of chloroquine against coronavirus: what to expect for COVID 19? Int J Antimicrob Agents [Forthcoming]. DOI: 10.1016/j. ijantimicag.2020.105938.

6. Gao J, Tian Z, Yang X. Breakthrough: chloroquine phosphate has shown apparent efficacy in treatment of COVID-19 associated pneumonia in clinical studies. BioScience Trends 2020;14(1):72-73. DOI: $10.5582 /$ bst.2020.01047.

7. Gautret P, Lagier JC, Parola P, Hoang VT, Meddeb L, Mailhe M, et al. Hydroxychloroquine and azithromycin as a treatment of COVID-19: results of an open-label non-randomized clinical trial. Int J Antimicrob Agents [Forthcoming]. DOI: 10.1016/j.jjantimicag.2020.105949 [in press].

8. Dong L, Hu S, Gao J. Discovering drugs to treat Coronavirus disease 2019 (COVID-19). Drug Discov Ther 2020;14(1):58-60. DOI: 10.5582/ ddt.2020.01012.

9. Zumla A, Chan JF, Azhar El, Hui DS, Yuen KY. Coronavirusesdrug discovery and therapeutic options. Nat Rev Drug Discov 2016;15(5):327-347. DOI: 10.1038/nrd.2015.37.

10. Haladyj E. Sikora M, Felis-Giemza A, Olesinska M. Antimalarialsare they effective and safe in rheumatic diseases? Reumatologia 2018;56(3):164-173. DOI: 10.5114/return.2018.76904.

11. Savarino A, Di Trani L, Donatelli I, Cauda R, Cassone A. New insights into the antiviral effects of chloroquine. Lancet Infect Dis 2006;6(2):67-69. DOI: 10.1016/S1473-3099(06)70361-9.

12. Yan Y, Zou Z, Sun Y, Li X, Xu KF, Wei Y, et al. Anti-malaria drug chloroquine is highly effective in treating avian influenza A H5N1 virus infection in an animal model. Cell Res 2012;23(2):300-302. DOI: 10.1038/cr.2012.165.

13. Inglot AD. Comparison of the antiviral activity in vitro of some nonsteroidal anti-inflammatory drugs. J Gen Virol 1969;4(2):203-214. DOI:10.1099/0022-1317-4-2-203.

14. Miller DK, Lenard J. Antihistaminics, local anesthetics, and other amines asantiviral agents. Proc Natl Acad Sci USA 1981;78(6):36053609. DOI: 10.1073/pnas.78.6.3605.

15. Shimizu Y, Yamamoto S, Homma M, Ishida N. Effect of chloroquine on thegrowth of animal viruses. Arch GesamteVirusforsch 1972;36:93104. DOI: $10.1007 /$ bf01250299.

16. Keyaerts E, Vijgen L, Maes P, Neyts J, RanstMV. In vitro inhibition of severe acute respiratory syndrome coronavirus by chloroquine. Biochem Biophys Res Commun 2004;323(1):264-268. DOI: 10.1016/j. bbrc.2004.08.085.

17. McChesney EW. Animal toxicity and pharmacokinetics of hydroxychloroquinesulfate. Am J Med 1983;75(1A):11-18. DOI: 10.1016/0002-9343(83)91265-2.

18. Savarino A, Boelaert JR, Cassone A, Majori G, Cauda R. Effects of chloroquine on viral infections: an old drug against today's diseases? Lancet Infect Dis 2003;3(11):722-727. DOI: 10.1016/s14733099(03)00806-5.

19. Keyaerts E, Li S, Vijgen L, Rysman E, Verbeeck J, Ranst MV. Antiviral activity of chloroquine against human coronavirus $\mathrm{OC} 43$ infection in newborn mice. Antimicrob Agents Chemother 2009;53(8):3416-3421. DOI: 10.1128/AAC.01509-08.

20. Vincent MJ, Bergeron E, Benjannet S, Erickson BR, Rollin PE, Ksiazek TG, et al. Chloroquine is a potent inhibitor of SARS coronavirus infection and spread. Virol J 2005;2:69. DOI: 10.1186/1743-422X-2-69.

21. Hu TY, Frieman M, Wolfram J. Insights from nanomedicine into chloroquine efficacy against COVID-19. Nat Nanotechnol 2020;15(4):247-249. DOI: 10.1038/s41565-020-0674-9.

22. Mauthe M, Orhon I, Rocchi C, Zhou X, Luhr M, Hijlkema KJ, et al. Chloroquine inhibits autophagic flux by decreasing autophagosome-lysosome fusion. Autophagy 2018;14(8):1435-1455. DOI: 10.1080/15548627.2018.1474314.

23. Pallister J, Middleton D, Crameri G, Yamada M, Klein R, Hancock TJ, et al. Chloroquine administration does not prevent Nipah virus infection and disease in ferrets. J Virol 2009;83(22):11979-11982. DOI: 10.1128/JVI.01847-09.
24. Liu J, $\mathrm{Cao}$ R, Xu M, Wang X, Zhang H, Hu H, et al. Hydroxychloroquine is a less toxic derivative of chloroquine, is effective in inhibiting SARS CoV-2 infection in vitro. Cell Discov 2020;6:16. DOI: 10.1038/s41421020-0156-0.

25. Wang M, Cao R, Zhang L, Yang X, Liu J, Xu M, et al. Remdesivir and chloroquine effectively inhibit the recently emerged novel coronavirus (2019-Ncov) in vitro. Cell Res 2020;30(3):269-271. DOI: 10.1038/s41422-020-0282-0.

26. Mackenzie AH. Dose refinements in long term therapy of rheumatoid arthritis with antimalarias. Am J Med 1983;75(1): 40-45. DOI: 10.1016/0002-9343(83)91269-X.

27. Touret $F$, de Lamballerie $X$. Of chloroquine and COVID-19. Antiviral Res 2020;177:104762. DOI: 10.1016/j.antiviral.2020.104762.

28. Higgins JPT, Spiegelhalter DJ. Being sceptical about meta-analyses; a Bayesian perspective on magnesium trials in myocardial infarction. Int Immunol J Epidemiol 2002;31(1):96-104. PUBMED 11914302.

29. Guyatt GH, Oxman AD, Vist GE, Kunz R, Falck-Ytter Y, Alonso-Coello P et al. GRADE: an emerging consensus on rating quality of evidence and strength recommendations. BMJ 2008;336(7650): 924-926. DOI: $10.1136 / \mathrm{bmj} .39489 .470347 . A D$.

30. Chen Z, Hu J, Zhang Z, Jiang S, Han S, Yan D, et al. Efficacy of hydroxychloroquine in patients with COVID-19: results of a randomized clinical trial. medRxiv [Forthcoming] DOI: 10.1101/2020.03.22.20040758.

31. Molina JM, Delaugerre C, Le Geoff J, Mela-Lima B, Ponscarme $D$, Goldwirt L, et al. No evidence of rapid antiviral clearance or clinical benefit with the combination of hydroxychloroquine and azithromycin in patients with severe COVID-19 infection. Med Mal Infect [Forthcoming]. DOI: 10.1016/j.medmal.2020.03.006.

32. Gautret P, Lagier JC, Parola P, Hoang VT, Meddeb L, Sevestre J, et al. Clinical and microbiological effect of a combination of hydroxychloroquine and azithromycin in 80 COVID-19 patients with at least a six-day follow up: a pilot observational study. Travel Med Infect Dis 2020;101663 [Forthcoming]. DOI: 10.1016/j.tmaid.2020.101663.

33. Geleris J, Sun Y, Platt J, Zucker J, Baldwin M, Hripcsak G, et al. Observational study of hydroxychloroquine in hospitalized patients with COVID-19. N Engl J Med 2020;382(25):2411-2418. DOI: 10.1056/ NEJMoa2012410.

34. Rosenberg ES, Dufort EM, Udo T, Wilberschied LA, Kumar J, Tersoreiro J, et al. Association of treatment with hydroxychloroquine or azithromycin with in-hospital mortality in patients with COVID-19 in New York state. JAMA 2020;323(24):2493-2502. DOI: 10.1001/ jama.2020.8630.

35. Tang W, Cao Z, Han M, WangZ, Chen J,Sun W, etal.Hydroxycholoroquine in patients with mainly mild to moderate Coronavirus disease 2019 open label, randomised controlled trial. BMJ 2020;369:m1849. DOI: 10.1136/bmj.m1849.

36. Mahevas M, Tran VT, Roumier M, Chanbrol A, Paule R, Guillaud C, et al. Clinical efficacy of hydroxychloroquine in patients with covid-19 pneumonia who require oxygen: observational comparative study using routine care data. BMJ 2020;369:m1844. DOI: 10.1136/bmj. m1844.

37. Magagnoli J, Narendran S, Pereira F, Cummings T, Hardin JM, Sutton SS, et al. Outcomes of hydroxycholoroquine usage in United States Veterans hospitalized with Covid-19. medRxiv 2020 [Forthcoming] DOI: 10.1101/2020.04.16.20065920; 10.1016/j.medj.2020.06.001.

38. Arshad S, Kilgore P, Chaudhry Z, O'Neill, Zervos M. Treatment with hydroxychloroquine, azithromycin, and combination in patients hospitalized with COVID-19. Int J Infect Dis 2020;97:396-403. DOI: 10/1016/j.ijid.2020.06.099.

39. The RECOVERY Collaborative Group. Effect of hydroxychloroquine in hospitalized patients with Covid-19. N Engl J Med 2020;383(21):20302040. DOI: 10.1056/NEJMoa.2022926.

40. WHO Solidarity Trial Consortium. Repurposed Antiviral drugs for Covid-19-Interim WHO Solidarity trial results. NEJM December 2, 2020. DOI: 10.1056/NEJMoa2023184. 